\title{
Repurposing itraconazole as an anticancer agent (Review)
}

\author{
HIROSHI TSUBAMOTO ${ }^{1,2}$, TOMOKO UEDA ${ }^{1}$, KAYO INOUE $^{1}$, KAZUKO SAKATA $^{1}$, \\ HIROAKI SHIBAHARA $^{1}$ and TAKASHI SONODA ${ }^{2}$ \\ ${ }^{1}$ Department of Obstetrics and Gynecology, Hyogo College of Medicine, Nishinomiya, Hyogo 663-8501; \\ ${ }^{2}$ Department of Medical Oncology, Meiwa Hospital, Nishinomiya, Hyogo 663-8186, Japan
}

Received December 30,2016; Accepted April 7, 2017

DOI: $10.3892 / 01.2017 .6325$

\begin{abstract}
Itraconazole, a common anti-fungal agent, has demonstrated potential anticancer activity, including reversing chemoresistance mediated by P-glycoprotein, modulating the signal transduction pathways of Hedgehog, mechanistic target of rapamycin and $\mathrm{Wnt} / \beta$-catenin in cancer cells, inhibiting angiogenesis and lymphangiogenesis, and possibly interfering with cancer-stromal cell interactions. Clinical trials have suggested the clinical benefits of itraconazole monotherapy for prostate cancer and basal cell carcinoma, as well as the survival advantage of combination chemotherapy for relapsed non-small cell lung, ovarian, triple negative breast, pancreatic and biliary tract cancer. As drug repurposing is cost-effective and timesaving, a review was conducted of preclinical and clinical data focusing on the anticancer activity of itraconazole, and discusses the future directions for repurposing itraconazole as an anticancer agent.
\end{abstract}

\section{Contents}

1. Introduction

2. Preclinical data

3. Clinical data

4. Future perspectives

\section{Introduction}

The development of anticancer drugs is a lengthy and expensive process (1). After a novel compound is identified or designed, preclinical and clinical data from phase I, II and III clinical trials are generated prior to approval. Drug repurposing represents the identification of the novel pharmacological effects of

Correspondence to: Dr Hiroshi Tsubamoto, Department of Obstetrics and Gynecology, Hyogo College of Medicine, 1-1 Mukogawa, Nishinomiya, Hyogo 663-8501, Japan

E-mail: tsuba@hyo-med.ac.jp

Key words: itraconazole, repurposing, repositioning, anticancer, P-glycoprotein, Hedgehog, Wnt/ $\beta$-catenin, mTOR, cancer-associated fibroblasts conventional drugs (2). As the pharmacokinetics, pharmacodynamics and safety in humans have already been established, expanding the application of a drug to additional diseases has advantages in terms of cost and time efficiency. Itraconazole is a common anti-fungal agent that was developed in the 1980s, which decreases ergosterol synthesis by inhibiting lanosterol $14 \alpha$-demethylase (14DM), resulting in the destruction of the fungal membrane (3). However, the anti-fungal effect of itraconazole is unlikely to be associated with its anticancer activity. Preclinical and clinical data have proposed the use of itraconazole as a promising anticancer agent in monotherapy or in combination chemotherapy (3). This review focuses on the efficacy of itraconazole in cancer treatment and ongoing clinical trials.

\section{Preclinical data}

Certain chemotherapeutic drugs induce expression of the drug efflux protein P-glycoprotein (P-gp), also known as multi-drug resistance 1 or ATP-binding cassette (ABC) transporter B1 (ABCB1). In the 1990s, itraconazole was demonstrated to reverse chemoresistance in cancer cells overexpressing P-gp (Fig. 1; Table I) (4-6). In addition, the human breast cancer resistance protein is also inhibited by itraconazole (7).

A screen of US Food and Drug Administration (FDA)approved drugs identified itraconazole as an anti-angiogenic agent in 2007 and as an inhibitor of Hedgehog signaling in $2010(8,9)$. Itraconazole inhibits AKT (protein kinase B)/mechanistic target of rapamycin (mTOR) signaling in human umbilical vein endothelial cells (HUVECs), glioblastoma, endometrial carcinoma (EC) and melanoma cells (10-14). Inhibition of Hedgehog signaling was observed in basal cell carcinoma, medulloblastoma, pleural mesothelioma, breast cancer and melanoma cells $(9,14-17)$, but not in EC cells (13). Inhibition of Wnt/ $\beta$-catenin signaling was observed in basal cell and examined in melanoma cells (14). Itraconazole also induced autophagic cell death in medulloblastoma cells as well as in breast cancer cells $(12,17)$, and suppressed lymphangiogenesis in lung carcinoma cells (18).

In HUVECs, itraconazole induced the accumulation of immature N-glycans on VEGFR2, which in turn inhibited autophosphorylation and downstream activation (19); itraconazole also exhibited synergistic effects with bevacizumab, a humanized monoclonal antibody against VEGF (20). Additionally, hypoglycosylation of the epidermal growth factor receptor was observed in renal cell carcinoma cells (19). 
Table I. Potential anticancer activities of itraconazole.

Modulation by itraconazole

Signaling pathways

mTOR

Hedgehog

Wnt $/ \beta$-catenin

AMPK

Autophagy

Microenvironment

Angiogenesis

Lymphangiogenesis

Cancer associated fibroblasts

Drug resistance

P-glycoprotein (MDR1, ABCB1)

BCRP/ABCG2

Transporter and pump of cholesterol

$\mathrm{SCP} 2$

ABCA1

NPC1
Cell types (Refs.)

HUVEC (10,11), glioblastoma (12), rat glioma (12),

EC (13), melanoma (14)

Mouse fibroblast (9), mouse medulloblastoma (9), mesothelioma (16), breast cancer (17), BCC (38), melanoma (14)

Melanoma (14)

HUVEC (11)

Glioblastoma (12), EC (13), breast cancer (17)

HUVEC $(8,10,11,25)$

Mouse lung cancer (18)

Colon cancer (20)

Pig kidney epithelial cells $(5,6)$

Breast cancer (7)

Glioblastoma (12), rat glioma (12)

EC (13)

HUVEC (25)

mTOR, mechanistic target of rapamycin; AMPK, AMP-activated protein kinase; MDR1, multi-drug resistance 1; ABCB1, ATP-binding cassette transporter B1; BCRP, breast cancer resistance protein; ABCG2, ATP-binding cassette transporter G2; SCP2, sterol carrier protein 2; ABCA1,ATP-binding cassette protein A1; NPC1, Niemann-Pick C1 protein; P-gp, P-glycoprotein; HUVEC, human umbilical vein endothelial cell; EC, endometrial carcinoma; BCC, basal cell carcinoma.

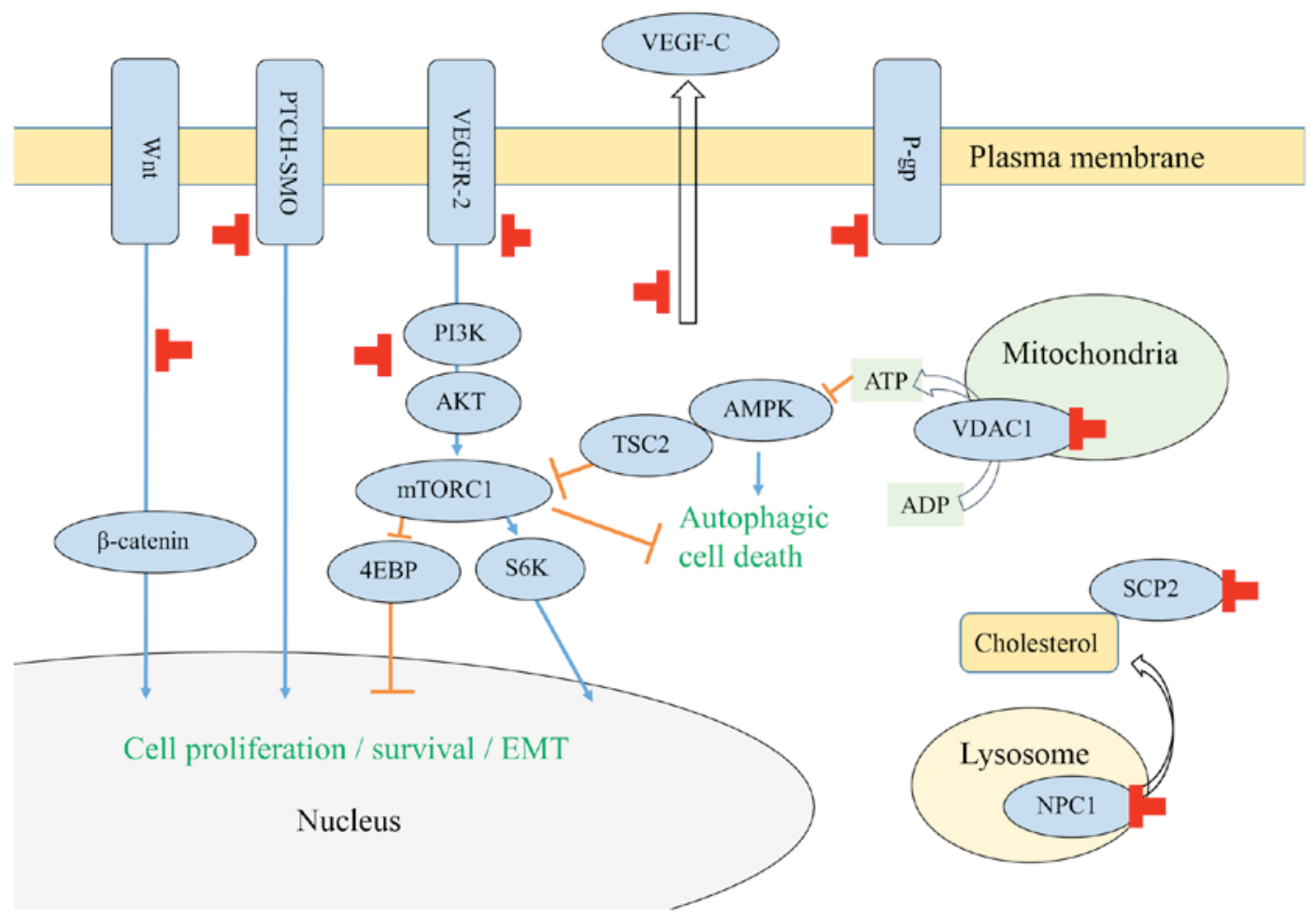

Figure 1. Schematic representation of the anticancer activity of itraconazole. AKT, protein kinase B; AMPK, AMP-activated protein kinase; 4EBP, eukaryotic translation initiation factor 4E binding protein; EMT, epithelial-mesenchymal transition; mTORC1, mechanistic target of rapamycin complex 1; NPC1, Niemann-Pick C1 protein; P-gp, P-glycoprotein; PI3K, phosphoinositide 3-kinase; PTCH-SMO, transmembrane receptor protein patched-transmembrane protein Smoothened (SMO); S6K, ribosomal protein S6 kinase; TSC2, tuberous sclerosis complex 2; VDAC1, voltage-dependent anion-selective channel 1; VEGF, vascular endothelial growth factor; VEGFR-2, VEGF receptor 2. 
Table II. Results of certain clinical trials.

\begin{tabular}{|c|c|c|c|c|c|c|c|}
\hline Cancer type & Phase & Eligibility & $\begin{array}{l}\text { No. of } \\
\text { previous } \\
\text { regimens }\end{array}$ & $\begin{array}{l}\text { No. patients } \\
\text { treated with } \\
\text { itraconazole }\end{array}$ & $\begin{array}{l}\text { Combination } \\
\text { chemotherapy }\end{array}$ & Results & (Refs.) \\
\hline Leukemia & $\begin{array}{l}\text { P2 RCT } \\
\text { sub-analysis }\end{array}$ & $\begin{array}{l}\text { ALL } \\
\text { AML }\end{array}$ & 0 & 27 & $\begin{array}{l}\text { Including } \\
\text { daunorubicin }\end{array}$ & $\begin{array}{l}\text { Tendency for } \\
\text { longer DFS in } \\
\text { itraconazole-treated } \\
\text { ALL patients } \\
(\mathrm{P}<0.06)\end{array}$ & (35) \\
\hline Ovarian & $\begin{array}{l}\text { Retrospective } \\
\text { comparative }\end{array}$ & $\begin{array}{l}\text { Progression } \\
\text { during previous } \\
\text { chemotherapy }\end{array}$ & $\geq 1$ & 19 & $\begin{array}{l}\text { Including } \\
\text { docetaxel }\end{array}$ & $\begin{array}{l}\mathrm{PFS} H R=0.24 \\
(\mathrm{P}=0.002) \mathrm{OS} \\
\mathrm{HR}=0.27(\mathrm{P}=0.006) \\
\text { in favor of the } \\
\text { itraconazole arm }\end{array}$ & (36) \\
\hline Ovarian & Retrospective & $\begin{array}{l}\text { Recurrent clear } \\
\text { cell carcinoma }\end{array}$ & $\geq 1$ & 9 & $\begin{array}{l}\text { Including } \\
\text { docetaxel } \\
\text { in } 8 \text { patients }\end{array}$ & $\begin{array}{l}\text { Median } \\
\text { OS } 34.9 \mathrm{~m} 95 \% \\
\text { CI, } 15.4-44.4 \mathrm{~m}\end{array}$ & (37) \\
\hline Breast & Retrospective & Triple negative & $\geq 2$ & 13 & $\begin{array}{l}\text { Including } \\
\text { docetaxel }\end{array}$ & $\begin{array}{l}\text { Median OS } 20.4 \mathrm{~m} \\
95 \% \mathrm{CI}, 13.1-41.4 \mathrm{~m}\end{array}$ & (38) \\
\hline Pancreatic & Retrospective & Relapse & $\geq 1$ & 38 & $\begin{array}{l}\text { Including } \\
\text { docetaxel }\end{array}$ & $\begin{array}{l}\text { Median OS } 11.4 \mathrm{~m} \\
95 \% \text { CI, 8.5-21.2 m }\end{array}$ & (39) \\
\hline Biliary tract & Retrospective & Relapse & $\geq 1$ & 28 & $\begin{array}{l}\text { Including } \\
\text { docetaxel }\end{array}$ & $\begin{array}{l}\text { Median OS } 12.0 \mathrm{~m} \\
95 \% \mathrm{CI}, 9.1-24.6 \mathrm{~m}\end{array}$ & $(40)$ \\
\hline NSCLC & P2 RCT & 2nd line & 1 & 15 & Pemetrexed & $\begin{array}{l}\mathrm{PFS} H \mathrm{HR}=0.399 \\
(\mathrm{P}=0.089) \mathrm{OS} \\
\mathrm{HR}=0.194 \\
(\mathrm{P}=0.012) \text { in favor } \\
\text { of itraconazole arm }\end{array}$ & (43) \\
\hline Prostate & P2 RCT & $\begin{array}{l}\text { Castration-resistant } \\
\text { chemo-naïve }\end{array}$ & 0 & 46 & None & $\begin{array}{l}\text { PSA-PFS at } \\
24 \text { weeks, } 11.8 \% \\
\text { vs. } 48.0 \% \text { in favor } \\
\text { of the high dose arm }\end{array}$ & (49) \\
\hline $\begin{array}{l}\text { Basal cell } \\
\text { carcinoma }\end{array}$ & P2 single arm & $\begin{array}{l}\geq 1 \text { tumor } \\
>4 \mathrm{~mm} \text { in diameter }\end{array}$ & 0 & 29 & None & $\begin{array}{l}\text { Decreased GLI1 } \\
\text { and Ki67 among } \\
\text { vismodegib-naïve } \\
8 \text { patients }\end{array}$ & $(51)$ \\
\hline
\end{tabular}

No., number; m, months; P2, phase 2; RCT, randomized controlled clinical trial; DFS, disease-free survival; PFS, progression-free survival; OS, overall survival; CI, confidence interval; PSA, prostate-specific antigen; ALL, acute lymphoblastic leukemia; AML, acute myeloid leukemia; NSCLC, non-small cell lung cancer.

Itraconazole directly binds to the mitochondrial protein voltage-dependent anion channel 1 (VDAC1) and interferes with mitochondrial ATP production, leading to the activation of the AMP-activated protein kinase pathway and the subsequent inhibition of mTOR activity (11).

In 1909, White (21) observed that cholesterol accumulated in tumor cells. Since then, such changes in the lipid composition of cancer cells have been studied in association with drug resistance. In the 1970 s, anti-fungal drugs were revealed to exert synergistic effects with certain chemotherapeutic drugs via altering the membrane lipid composition of cancer cells $(22,23)$, and therapeutic strategies that target lipogenic enzymes have been investigated in preclinical and clinical studies (24). Aberrant activation of AKT is correlated with an increase in lipid raft formation, while the disruption of lipid rafts inhibits AKT activation (25). In HUVECs, itraconazole inhibited intracellular cholesterol trafficking to the plasma membrane by binding to Niemann-Pick $\mathrm{C} 1$ protein, resulting in cholesterol depletion (26). In glioblastoma cells, the redistribution of cholesterol was induced by the downregulation of sterol carrier protein (SCP2) (12), which is located in numerous organelles including mitochondria (27). In EC cells, the transcription of SCP2 was observed to be unaffected by itraconazole treatment. Among EC cells that were unaffected by itraconazole, the cholesterol efflux protein ABCA1 was downregulated (13).

The tumor microenvironment serves a key role in the cell proliferation, invasion and metastasis in cancer (28); however, the exact underlying mechanisms of cancer-stromal interactions are poorly understood. Cancer-associated fibroblasts 
Table III. Ongoing clinical trials.

\begin{tabular}{|c|c|c|c|c|c|c|}
\hline $\begin{array}{l}\text { Type of } \\
\text { cancer }\end{array}$ & Phase & Prior chemo & $\begin{array}{l}\text { Primary } \\
\text { endpoint }\end{array}$ & Treatment & $\begin{array}{l}\text { Clinical trial } \\
\text { identifier }\end{array}$ & $\begin{array}{l}\text { Institution of principal } \\
\text { investigator }\end{array}$ \\
\hline Solid tumor & $\begin{array}{l}\text { Window } \\
\text { trial }\end{array}$ & - & $\mathrm{Ki}-67$ index & Itra 400 mg BID & UMIN000018388 & $\begin{array}{l}\text { Hyogo College } \\
\text { of Medicine }\end{array}$ \\
\hline NSCLC & $\mathrm{P} 0$ & Chemo-naïve & $\begin{array}{l}\text { Tissue microvessel } \\
\text { density }\end{array}$ & Itra 600 mg BID & NCT02357836 & $\begin{array}{l}\text { University of } \\
\text { Texas Southwestern } \\
\text { Medical Center }\end{array}$ \\
\hline $\begin{array}{l}\text { Basal cell } \\
\text { carcinoma }\end{array}$ & $\mathrm{P} 0$ & - & $\begin{array}{l}\text { GLI1 mRNA } \\
\text { expression }\end{array}$ & Itra ointment & NCT02735356 & $\begin{array}{l}\text { Stanford Cancer } \\
\text { Institute }\end{array}$ \\
\hline $\begin{array}{l}\text { Esophageal } \\
\text { cancer }\end{array}$ & $\mathrm{P} 1$ & - & $\begin{array}{l}\text { Hh mRNA } \\
\text { expression }\end{array}$ & Itra 300 mg BID & NCT02749513 & $\begin{array}{l}\text { Dallas VA } \\
\text { Medical Center }\end{array}$ \\
\hline Glioblastoma & $\mathrm{P} 1$ & - & Toxicity & $\begin{array}{l}\text { Multi-agent cocktail } \\
\text { including Itra }\end{array}$ & NCT02770378 & $\begin{array}{l}\text { University of Ulm } \\
\text { School of Medicine }\end{array}$ \\
\hline Prostate cancer & $\mathrm{P} 2$ & Chemo-naïve & Decline of PSA & Itra 300 mg BID & NCT01787331 & $\begin{array}{l}\text { University of } \\
\text { California }\end{array}$ \\
\hline $\begin{array}{l}\text { Gynecological } \\
\text { cancer }\end{array}$ & $\mathrm{P} 2$ & $\geq 2$ nd line & PFS & $\begin{array}{l}\text { DOC/Gem } \\
\text { Itra } 400 \text { mg BID }\end{array}$ & UMIN000013951 & $\begin{array}{l}\text { Hyogo College } \\
\text { of Medicine }\end{array}$ \\
\hline NSCLC & $\mathrm{P} 2$ & Chemo-naïve & Response rate & $\begin{array}{l}\text { Nab-P/Carbo/Bev } \\
\text { Itra } 400 \text { mg BID }\end{array}$ & UMIN000019049 & Meiwa Hospital \\
\hline Gastric cancer & $\mathrm{P} 2$ & Chemo-naïve & $\begin{array}{l}\text { Response rate } \\
\text { operability }\end{array}$ & $\begin{array}{l}\text { Nab-P/Ox/S-1 } \\
\text { Itra } 400 \text { mg BID }\end{array}$ & UMIN000021340 & Meiwa Hospital \\
\hline $\begin{array}{l}\text { Pancreatic } \\
\text { cancer }\end{array}$ & $\mathrm{P} 2$ & Chemo-naïve & $\begin{array}{l}\text { Response rate } \\
\text { operability }\end{array}$ & $\begin{array}{l}\text { Nab-P/Ox/Gem } \\
\text { Itra } 400 \text { mg BID }\end{array}$ & UMIN000029075 & Meiwa Hospital \\
\hline
\end{tabular}

All trials are recruiting participants in March, 2017. NSCLC, non-small cell lung cancer; GLI1, Glioma-Associated Oncogene Homolog 1; Hh, hedgehog; PSA, prostate-specific antigen; PFS, progression-free survival; Itra, itraconazole; BID, twice a day; DOC, docetaxel; Gem, gemcitabine; nab-P, nanoparticle albumin-bound paclitaxel; Carbo, carboplatin; Bev, bevacizumab; Ox, oxaliplatin; S1, tegafur/gimeracil/oteracil; Tem, temozolomide.

(CAFs) are essential for tumor growth (29). Itraconazole inhibited the proliferation of CAFs established from human colon cancer cells, as well as the secretion of monocyte chemoattractant protein-1 (20). Monocyte/macrophage marker CD14 is a glycosylphosphatidylinositol-anchored glycoprotein present in cholesterol-rich lipid rafts, which contain a variety of signaling proteins and receptors $(30,31)$. In mouse macrophages, itraconazole treatment altered the N-glycosylation of CD14, and increased CD14 transcription and protein expression (32).

\section{Clinical data}

In a randomized trial of leukemia, anti-fungal prophylactic treatment with itraconazole was proven to be effective and safe in patients receiving remission induction therapy, including daunorubicin (33). Based on preclinical data detailing the reversal of daunorubicin resistance by itraconazole (34), a sub-analysis of itraconazole anticancer activity was conducted in 27 patients with acute lymphoblastic leukemia (35), and itraconazole treatment was likely to be associated with improved disease-free survival (Table II). The results of the clinical trial (35), as well as preclinical data on itraconazole reversing the resistance of taxane-resistant cancer cells $(5,6)$, supported the treatment of refractory solid tumors with taxane-based chemotherapy in combination with itraconazole. A prior retrospective study demonstrated that overall survival (OS) was prolonged in 19 patients with refractory ovarian cancer, who had been treated with taxane-based chemotherapy with itraconazole (36). Additional retrospective studies supported the survival advantage of itraconazole treatment in refractory malignancies including ovarian clear cell, triple-negative breast, pancreatic and biliary tract cancer, as compared with the previous reports (37-40). In pancreatic cancer, itraconazole treatment combined with chemotherapy was conducted in progressive disease during chemotherapy (39). A total of 38 patients received docetaxel $\left(35 \mathrm{mg} / \mathrm{m}^{2}\right)$, gemcitabine $\left(1,000 \mathrm{mg} / \mathrm{m}^{2}\right)$ and carboplatin $(4 \mathrm{mg} / \mathrm{min} / \mathrm{ml})$ in combination with itraconazole $(400 \mathrm{mg})$, following which a median OS of 11.4 months was observed. In addition, 28 patients with biliary tract cancer received itraconazole, and subsequently experienced a median OS of 12 months (40).

With the aim of enhancing the therapeutic efficacy of anticancer drugs, P-gp inhibitors were investigated in a clinical trial (41) that reported unsatisfactory outcomes. The phase III study was conducted in the ovarian cancer patients, in whom the paclitaxel dose was reduced from $175 \mathrm{mg} / \mathrm{m}^{2}$ in control patients to $80 \mathrm{mg} / \mathrm{m}^{2}$ with valspodar ( $5 \mathrm{mg} / \mathrm{kg}$ every $6 \mathrm{~h}$ for 12 doses) for patients undergoing the combination therpay (42). The addition of valspodar to standard chemotherapy regimens did not significantly improve progression-free survival (PFS) or OS, but increased the frequency of adverse events experienced. Therefore, the 
survival advantage conveyed by combination chemotherapy with itraconazole among patients with various types of cancer could not be explained by P-gp inhibition alone. Repurposing itraconazole for the targeting of angiogenesis has been examined since 2009. In a randomized phase II clinical trial of non-small cell lung cancer (43), 23 patients were enrolled in the second-line setting. Of these, 15 patients who were treated with pemetrexed $\left(500 \mathrm{mg} / \mathrm{m}^{2}\right.$, repeated every 21 days) and oral itraconazole (200 $\mathrm{mg}$, daily) exhibited a prolonged OS time, as compared with the 8 patients who were treated with pemetrexed alone. A meta-analysis of randomized trials demonstrated that the VEGF inhibitor bevacizumab prolonged OS in colorectal, non-small cell lung and cervical cancer, but not in breast or ovarian cancer (44). Phase III trials of the VEGFR inhibitor ramucirumab reported prolonged OS in non-small cell lung, gastric and colorectal cancer, (45-48). Considering the results of the clinical trials using P-gp inhibitor or antiangiogenic agents (41,43-47), the clinical efficacy of itracoanzole treatment in various types of cancer (Table II) implicated the additional anticancer activities, which was demonstrated in preclinical studies (Table I).

In a randomized phase II clinical trial of metastatic castration-resistant prostate cancer (49), 46 chemotherapy-naïve patients were enrolled, of whom 29 received high-dose (600 mg/day) and 17 received low-dose (200 mg/day) itraconazole treatment. Prostate-specific antigen PFS rates at 24 weeks were 48.0 and $11.8 \%$ with median PFS of 11.9 and 35.9 weeks in the high- and low-dose arm, respectively. Plasma VEGF levels remained unchanged following itraconazole treatment in both arms, whereas the down-modulation of GLI1 was significantly correlated with the decline of PSA.

Basal cell carcinoma, the most common type of skin cancer, is associated with upregulated Hedgehog signaling, and two Hedgehog inhibitors, vismodegib and sonidegib, which target Smoothened have been approved by the FDA for treatment of basal cell carcinoma (50). In a recent study conducted on 29 patients with basal cell carcinoma (19 treated with itraconazole) (51), it was observed that the tumor area decreased by an average of $24 \%$ in 8 of the itraconazole-treated patients with accessible lesions. Among the vismodegib-naïve patients $(n=8)$, the transcription of GLI1 and Ki-67 activity was significantly decreased after itraconazole treatment (51).

\section{Future perspectives}

Following exposure to cytotoxic agents, the residual tumors typically harbor cancer stem cells (CSCs) or develop stemness (52). The concept of CSCs was hypothesized to explain metastasis and recurrence following exposure to chemotherapy (53); CSCs are characterized by self-renewal, multi-differentiation and chemoresistance. Additional potential mechanisms underlying chemotherapy resistance may include dormant cell cycles, multidrug resistance transporters and protection by niche cells. The current focus is on the development of CSC-targeted therapy for preventing cancer relapse and improving survival rates (54). Aberrant signaling pathways, including AKT/mTOR, Hedgehog, and Wnt, have been reported in CSCs and multi-targeting therapies have been proposed (54). The first-in-class cancer stemness inhibitor napabucasin (BBI 608), which targets signal transducer and activator of transcription 3 (Stat3), Nanog, and Wnt/ $\beta$-catenin pathways, has been reported to improve OS in patients with positive phospho-STAT3 recurrent colorectal cancer $(55,56)$. Itraconazole may be a promising agent for targeting CSCs in relapsed disease of multiple types of cancer; therefore, further preclinical studies on CSCs and the surrounding stroma cells are warranted.

Ongoing clinical trials with itraconazole (as an anticancer agent) were identified from ClincalTrials.gov (https:/clinicaltrials.gov/ct2/home) and UMIN-CTR Search Clinical Trials (http://www.umin.ac.jp/ctr/index.htm), as well as Google search (Table III). No ongoing clinical trials were registered at the EU Clinical Trial Register (https://www.clinicaltrialsregister.eu/ctr-search/search). Obtaining cancer tissues and blood from patients prior to and following itraconazole treatment is essential for exploring and characterizing novel targets in the tumor and the microenvironment, as well as for identifying biomarkers predictive of patient response for future enrichment clinical trials.

\section{References}

1. Siddiqui $\mathrm{M}$ and Rajkumar SV: The high cost of cancer drugs and what we can do about it. Mayo Clin Proc 87: 935-943, 2012.

2. Pantziarka P, Bouche G, Meheus L, Sukhatme V, Sukhatme VP and Vikas P: The repurposing drugs in oncology (ReDO) project. Ecancermedicalscience 8: 442, 2014.

3. Pantziarka P,Sukhatme V,Bouche G, Meheus L and Sukhatme VP: Repurposing drugs in oncology (ReDO)-itraconazole as an anti-cancer agent. Ecancermedicalscience 9: 521, 2015.

4. Kurosawa M, Okabe M, Hara N, Kawamura K, Suzuki S Sakurada K and Asaka M: Reversal effect of itraconazole on adriamycin and etoposide resistance in human leukemia cells. Ann Hematol 72: 17-21, 1996.

5. Takara K, Tanigawara Y, Komada F, Nishiguchi K, Sakaeda T and Okumura K: Cellular pharmacokinetic aspects of reversal effect of itraconazole on P-glycoprotein-mediated resistance of anticancer drugs. Biol Pharm Bull 22: 1355-1359, 1999.

6. Shirakawa K, Takara K, Tanigawara Y, Aoyama N, Kasuga M, Komada F, Sakaeda T and Okumura K: Interaction of docetaxel ('Taxotere') with human P-glycoprotein. Jpn J Cancer Res 90: 1380-1386, 1999.

7. Gupta A, Unadkat JD and Mao Q: Interactions of azole antifungal agents with the human breast cancer resistance protein (BCRP). J Pharm Sci 96: 3226-3235, 2007.

8. Chong CR, Xu J, Lu J, Bhat S, Sullivan DJ Jr and Liu JO: Inhibition of angiogenesis by the antifungal drug itraconazole. ACS Chem Biol 2: 263-270, 2007.

9. Kim J, Tang JY, Gong R, Kim J, Lee JJ, Clemons KV, Chong CR, Chang KS, Fereshteh M, Gardner D, et al: Itraconazole, a commonly used antifungal that inhibits Hedgehog pathway activity and cancer growth. Cancer Cell 17: 388-399, 2010.

10. Xu J, Dang Y, Ren YR and Liu JO: Cholesterol trafficking is required for mTOR activation in endothelial cells. Proc Natl Acad Sci USA 107: 4764-4769, 2010.

11. Head SA, Shi W, Zhao L, Gorshkov K, Pasunooti K, Chen Y, Deng Z, Li RJ, Shim JS, Tan W, et al: Antifungal drug itraconazole targets VDAC1 to modulate the AMPK/mTOR signaling axis in endothelial cells. Proc Natl Acad Sci USA 112: E7276-E7285, 2015.

12. Liu R, Li J, Zhang T, Zou L, Chen Y, Wang K, Lei Y, Yuan K, Li Y, Lan J, et al: Itraconazole suppresses the growth of glioblastoma through induction of autophagy: Involvement of abnormal cholesterol trafficking. Autophagy 10: 1241-1255, 2014.

13. Tsubamoto $H$, Inoue $K$, Sakata $K$, Ueda $T$, Takeyama $R$, Shibahara $\mathrm{H}$ and Sonoda T: Itraconazole inhibits Akt/mTOR signalling and proliferation in endometrial cancer cells. Anticancer Res 37: 515-519, 2017.

14. Liang G, Liu M, Wang Q, Shen Y, Mei H, Li D and Liu W: Itraconazole exerts its anti-melanoma effect by suppressing Hedgehog, Wnt, and PI3K/mTOR signaling pathways. Oncotarget 8: 28510-28525, 2017. 
15. Kim J, Aftab BT, Tang JY, Kim D, Lee AH, Rezaee M, Kim J, Chen B, King EM, Borodovsky A, et al: Itraconazole and arsenic trioxide inhibit Hedgehog pathway activation and tumor growth associated with acquired resistance to smoothened antagonists Cancer Cell 23: 23-34, 2013.

16. You M, Varona-Santos J, Singh S, Robbins DJ, Savaraj N and Nguyen DM: Targeting of the Hedgehog signal transduction pathway suppresses survival of malignant pleural mesothelioma cells in vitro. J Thorac Cardiovasc Surg 147: 508-516, 2014.

17. Wang X, Wei S, Zhao Y, Shi C, Liu P, Zhang C, Lei Y, Zhang B, Bai B, Huang Y and Zhang H: Anti-proliferation of breast cancer cells with itraconazole: Hedgehog pathway inhibition induces apoptosis and autophagic cell death. Cancer Lett 385: 128-136, 2017.

18. Wang Y, Yao Y, Liu H, Ma X, Lv T, Yuan D, Xiao X, Yin J and Song Y: Itraconazole can inhibit malignant pleural effusion by suppressing lymphangiogenesis in mice. Trans Lung Cancer Res 4: 27-35, 2015

19. Nacev BA, Grassi P, Dell A, Haslam SM and Liu JO: The antifungal drug itraconazole inhibits vascular endothelial growth factor receptor 2 (VEGFR2) glycosylation, trafficking, and signaling in endothelial cells. J Biol Chem 286: 44045-44056, 2011.

20. Hara M, Nagasaki T, Shiga K and Takeyama H: Suppression of cancer-associated fibroblasts and endothelial cells by itraconazole in bevacizumab-resistant gastrointestinal cancer. Anticancer Res 36: 169-177, 2016.

21. White CP: On the occurrence of crystals in tumours. J Pathol Bacteriol 13: 3-10, 1909.

22. Kuwano M, Kamiya T, Endo H and Komiyama S: Potentiation of 5-fluorouracil, chromomycin A3, and bleomycin by amphotericin B or polymyxin B in transformed fibroblastic cells. Antimicrob Agents Chemother 3: 580-584, 1973.

23. Ikezaki K, Akiyama S, Miyazaki C, Kimura G and Kuwano M: Imidazole-resistant phenotype and virus transformation in cultured rat cells. Cancer Res 44: 1791-1795, 1984.

24. Beloribi-Djefaflia S, Vasseur S and Guillaumond F: Lipid metabolic reprogramming in cancer cells. Oncogenesis 5: e189, 2016.

25. Calay D, Vind-Kezunovic D, Frankart A, Lambert S, Poumay Y and Gniadecki R: Inhibition of Akt signaling by exclusion from lipid rafts in normal and transformed epidermal keratinocytes. J Invest Dermatol 130: 1136-1145, 2010.

26. Head SA, Shi WQ, Yang EJ, Nacev BA, Hong SY, Pasunooti KK, Li RJ, Shim JS and Liu JO: Simultaneous targeting of NPC1 and VDAC1 by itraconazole leads to synergistic inhibition of mTOR signaling and angiogenesis. ACS Chem Biol 12: 174-182, 2017.

27. Gallegos AM, Atshaves BP, Storey SM, Starodub O, Petrescu AD Huang $\mathrm{H}$, McIntosh AL, Martin GG, Chao H, Kier AB and Schroeder F: Gene structure, intracellular localization, and functional roles of sterol carrier protein-2. Prog Lipid Res 40 : 498-563, 2001.

28. Plaks V, Kong $\mathrm{N}$ and Werb Z: The cancer stem cell niche: How essential is the niche in regulating stemness of tumor cells? Cell Stem Cell 16: 225-238, 2915

29. Kalluri R and Zeisberg M: Fibroblasts in cancer. Nat Rev Cancer 6: 392-401, 2006.

30. Schmitz G and Orsó E: CD14 signalling in lipid rafts: New ligands and co-receptors. Curr Opin Lipidol 13: 513-521, 2002.

31. Martinez-Outschoorn UE, Sotgia F and Lisanti MP: Caveolae and signalling in cancer. Nat Rev Cancer 15: 225-237, 2015.

32. Frey $\mathrm{T}$ and De Maio A: The antifungal agent itraconazole induces the accumulation of high mannose glycoproteins in macrophages. J Biol Chem 284: 16882-16890, 2009.

33. Vreugdenhil G, Van Dijke BJ, Donnelly JP, Novakova IR Raemaekers JM, Hoogkamp-Korstanje MA, Koster M and de Pauw BE: Efficacy of itraconazole in the prevention of fungal infections among neutropenic patients with hematologic malignancies and intensive chemotherapy. A double blind, placebo controlled study. Leuk Lymphoma 11: 353-358, 1993.

34. Gupta S, Kim J and Gollapudi S: Reversal of daunorubicin resistance in P388/ADR cells by itraconazole. J Clin Invest 87 : 1467-1469, 1991

35. Vreugdenhil G, Raemaekers JM, van Dijke BJ and de Pauw BE: Itraconazole and multidrug resistance: Possible effects on remission rate and disease-free survival in acute leukemia. Ann Hematol 67: 107-109, 1993

36. Tsubamoto H, Sonoda T, Yamasaki M and Inoue K: Impact of combination chemotherapy with itraconazole on survival of patients with refractory ovarian cancer. Anticancer Res 34: 2481-2487, 2014
37. Tsubamoto H, Sonoda T, Yamasaki M and Inoue K: Impact of combination chemotherapy with itraconazole on survival for patients with recurrent or persistent ovarian clear cell carcinoma. Anticancer Res 34: 2007-2014, 2014.

38. Tsubamoto H, Sonoda $\mathrm{T}$ and Inoue K: Impact of itraconazole on the survival of heavily pre-treated patients with triple-negative breast cancer. Anticancer Res 34: 3839-3844, 2014

39. Tsubamoto $H$, Sonoda $T$, Ikuta $S$, Tani $S$, Inoue $K$ and Yamanaka N: Combination chemotherapy with itraconazole for treating metastatic pancreatic cancer in the second-line or additional setting. Anticancer Res 35: 4191-4196, 2015.

40. Tsubamoto H, Sonoda T, Ikuta S, Tani S, Inoue $\mathrm{K}$ and Yamanaka N: Impact of itraconazole after first-line chemotherapy on survival of patients with metastatic biliary tract cancer. Anticancer Res 35: 4923-4927, 2015.

41. Chung FS, Santiago JS, Jesus MF, Trinidad CV and See MF: Disrupting P-glycoprotein function in clinical settings: What can we learn from the fundamental aspects of this transporter? Am J Cancer Res 6: 1583-1598, 2016.

42. Lhommé C, Joly F, Walker JL, Lissoni AA, Nicoletto MO, Manikhas GM, Baekelandt MM, Gordon AN, Fracasso PM, Mietlowski WL, et al: Phase III study of valspodar (PSC 833) combined with paclitaxel and carboplatin compared with paclitaxel and carboplatin alone in patients with stage IV or suboptimally debulked stage III epithelial ovarian cancer or primary peritoneal cancer. J Clin Oncol 26: 2674-2682, 2008

43. Rudin CM, Brahmer JR, Juergens RA, Hann CL, Ettinger DS, Sebree R, Smith R, Aftab BT, Huang P and Liu JO: Phase 2 study of pemetrexed and itraconazole as second-line therapy for metastatic nonsquamous non-small-cell lung cancer. J Thorac Oncol 8: 619-623, 2013

44. Roviello G, Bachelot T, Hudis CA, Curigliano G, Reynolds AR, Petrioli R and Generali D: The role of bevacizumab in solid tumours: A literature based meta-analysis of randomised trials. Eur J Cancer 75: 245-258, 2017.

45. Garon EB, Ciuleanu TE, Arrieta O, Prabhash K, Syrigos KN, Goksel T, Park K, Gorbunova V, Kowalyszyn RD, Pikiel J, et al: Ramucirumab plus docetaxel versus placebo plus docetaxel for second-line treatment of stage IV non-small-cell lung cancer after disease progression on platinum-based therapy (REVEL): A multicentre, double-blind, randomised phase 3 trial. Lancet 384: 665-673, 2014.

46. Fuchs CS, Tomasek J, Yong CJ, Dumitru F, Passalacqua R, Goswami C, Safran H, dos Santos LV, Aprile G, Ferry DR, et al: Ramucirumab monotherapy for previously treated advanced gastric or gastro-oesophageal junction adenocarcinoma (REGARD): An international, randomised, multicentre, placebo-controlled, phase 3 trial. Lancet 383: 31-39, 2014.

47. Wilke H, Muro K, Van Cutsem E, Oh SC, Bodoky G, Shimada Y, Hironaka S, Sugimoto N, Lipatov O, Kim TY, et al: Ramucirumab plus paclitaxel versus placebo plus paclitaxel in patients with previously treated advanced gastric or gastro-oesophageal junction adenocarcinoma (RAINBOW): A double-blind, randomised phase 3 trial. Lancet Oncol 15: $1224-1235,2014$

48. Tabernero J, Yoshino T, Cohn AL, Obermannova R, Bodoky G, Garcia-Carbonero R, Ciuleanu TE, Portnoy DC, Van Cutsem E, Grothey A, et al: Ramucirumab versus placebo in combination with second-line FOLFIRI in patients with metastatic colorectal carcinoma that progressed during or after first-line therapy with bevacizumab, oxaliplatin, and a fluoropyrimidine (RAISE): A randomised, double-blind, multicentre, phase 3 study. Lancet Oncol 16: 499-508, 2015.

49. Antonarakis ES, Heath EI, Smith DC, Rathkopf D, Blackford AL, Danila DC, King S, Frost A, Ajiboye AS, Zhao M, et al: Repurposing itraconazole as a treatment for advanced prostate cancer: A noncomparative randomized phase II trial in men with metastatic castration-resistant prostate cancer. Oncologist 18: 163-173, 2013.

50. NCCN: Clinical practice guidelines in oncology, basal cell skin cancer, version 1, 2017. https://www.nccn.org/professionals/physician_gls/pdf/nmsc.pdf. Accessed April 20, 2017.

51. Kim DJ, Kim J, Spaunhurst K, Montoya J, Khodosh R, Chandra K, Fu T, Gilliam A, Molgo M, Beachy PA and Tang JY: Open-label, exploratory phase II trial of oral itraconazole for the treatment of basal cell carcinoma. J Clin Oncol 32: 745-751, 2014.

52. Zhou BB, Zhang H, Damelin M, Geles KG, Grindley JC and Dirks PB: Tumour-initiating cells: Challenges and opportunities for anticancer drug discovery. Nat Rev Drug Discov 8: 806-823, 2009. 
53. Zhao J: Cancer stem cells and chemoresistance: The smartest survives the raid. Pharmacol Ther 160: 145-158, 2016.

54. Ahmed M, Chaudhari K, Babaei-Jadidi R, Dekker LV and Shams Nateri A: Concise Review: Emerging drugs targeting epithelial cancer stem-like cells. Stem Cells 35: 839-850, 2017.

55. Li Y, Rogoff HA, Keates S, Gao Y, Murikipudi S, Mikule K, Leggett D, Li W, Pardee AB and Li CJ: Suppression of cancer relapse and metastasis by inhibiting cancer stemness. Proc Natl Acad Sci USA 112: 1839-1844, 2015.
56. Jonker DJ, Nott L, Yoshino T, Gill S, Shapiro J, Ohtsu A, Zalcerg J, vickers MM, Wei A, Gao Y, et al: A randomized phase III study of napabucasin [BBI608] (NAPA) vs placebo (PBO) in patients (pts) with pretreated advanced colorectal cancer (ACRC): The CCTG/AGITG CO.23 trial. Ann Oncol 27 (Suppl 6): S454O, 2016. 